\title{
sciendo
}

CIVIL AND ENVIRONMENTAL ENGINEERING REPORTS

E-ISSN 2450-8594

CEER 2021; 31 (1): 0161-0171

DOI: $10.2478 /$ ceer-2021-0011

Original Research Article

\section{THE RELATIONSHIP BETWEEN THE BIOKINETIC PARAMETERS OF AN AEROBIC GRANULAR SLUDGE SYSTEM AND THE APPLIED OPERATING CONDITIONS}

\author{
Nur Ain HAMIRUDDIN, Nik Azimatolakma AWANG ${ }^{1}$ \\ School of Civil Engineering, Engineering Campus, Universiti Sains Malaysia, Nibong \\ Tebal, 14300 Pulau Pinang, Malaysia
}

\begin{abstract}
Biokinetic parameters help to describe the rate of substrate utilization and biomass production or growth by microbial action, which is important to the design process and performance optimization of wastewater treatment. Although studies of the biokinetic parameters of aerobic granular sludge (AGS) systems have been increasing lately, the significance for each value in terms of maximum specific growth rate $\left(\mu_{\max }\right)$, substrate concentration at one-half of the maximum specific growth rate $\left(\mathrm{K}_{\mathrm{S}}\right)$, and cell yield $(\mathrm{Y})$ in relation to the applied operating conditions are rarely discussed. Therefore, this study investigates the relationship and significance between the above-stated biokinetic parameters with organic loading rate (OLR) and reactor height/diameter (H/D) ratio from five different batches of AGS treated sewage, using the independent t-test. The biokinetic parameters are summarized as biomass production $\left(Y\right.$ and $\left.\mu_{\max }\right)$ and relied upon the relative increase in the OLR and reactor H/D ratios. Additionally, aerobic granules developed in reactors with a high $\mathrm{H} / \mathrm{D}$ ratio have a shorter setup time and are more active in contrast with low $\mathrm{H} / \mathrm{D}$ ratio reactors.
\end{abstract}

Keywords: biokinetic parameters, height/diameter (H/D), independent t-test, organic loading rate (OLR), sewage

${ }^{1}$ Corresponding author: Awang NA, School of Civil Engineering, Engineering Campus, Universiti Sains Malaysia, Nibong Tebal, 14300 Pulau Pinang, Malaysia, Tel: +6045996213 


\section{INTRODUCTION}

Biokinetic coefficients are the basis for wastewater treatment plant (WWTP) design [1]. Some of these biokinetic coefficients are also used in operating the WWTP such as yield coefficient and decay coefficient $(\mathrm{kd})$. There are several studies of biokinetic coefficient determination in different processes that have focused on the kinetics of crossflow membrane bioreactor processes (CF-MBR) in the treatment of refinery wastewater [2]. The bioreactor operated under two mixed liquor suspended solids (MLSS) with values of 3000 and $5000 \mathrm{mg} / \mathrm{L}$. The high retention time (HRT) value and calculated biokinetic coefficients in each MLSS were also adjusted. Besides this, a study by Mardani et al. [3] determined the biokinetic coefficients for activated sludge processes such as conventional, extended aeration, and contact stabilization on municipal wastewater.

The investigation showed that the yield coefficient $(\mathrm{Y})$, decay coefficient $(\mathrm{kd})$, maximum specific growth rate, and saturation constant (KS) for conventional and contact stabilization processes were in the approved range. However, in the extended aeration process, values of Ks and Y in the MLSS of $5000 \mathrm{mg} / \mathrm{L}$ were out of range [3]. In addition, a study by Okpokwasili and Nweke [4] determined the biokinetic parameters in municipal wastewater treatment with a submerged MBR using the Monod equation. Their results showed that the Y, kd, KS , and $\mu \max$ coefficients were in the range of the Monod equation [5]. Furthermore, Amaldos et al., [6] determined the biokinetics of wastewater treatment in a highperformance compact reactor using different cell residence times.

Most of the previous studies reporting biokinetic coefficients are based on a WWTP design of CF-MBR, Up-flow, or an activated sludge process [7]. In this study, the significance of biokinetic parameters including $\mu$ max, KS, and Y will be discussed to determine the relationship between changes in the kinetic coefficients with organic loading rate (OLR) and reactor height/diameter (H/D) ratio, taken from five different batches of aerobic granules.

\section{MATERIAL}

The source of data used in this study is based on a previous study by Awang and Shaaban [1] on the effects of reactor height/diameter ratio and organic loading rate on the formation of aerobic granular sludge in sewage treatment. The biokinetic parameters $(\mathrm{k}, \mathrm{Ks}, \mathrm{Y}, \mathrm{Kd}$, and mmax) of aerobic granules that developed in an SBR with sewage as a substrate were analyzed using a linear plot. The difference in biokinetic parameter ( $\mathrm{k}, \mathrm{Ks}, \mathrm{Y}, \mathrm{Kd}$, and mmax) values gathered from five aerobic granules batches were tested to establish whether there is a linear correlation with the variable organic loading rate (OLR) and reactor height/diameter (H/D) ratio. 


\section{TESTING METHOD}

\subsection{The Independent t-test}

The independent t-test is utilized to determine if two sample means, which are assumed to come from two independent populations, are statistically different. In an independent group design, there are different samples of subjects [8]. The populations are assumed to differ only in the degree of the independent variable. Thus, it is assumed there are two independent samples, each sample originating from its own independent population, with each population differing by only the degree of an independent variable [9]. Hence, any difference found between the sample means ought to exist between population means, and any difference between the population means must be because of the difference in the degrees of the independent variable.

The data are visualized as group statistics for a reactor with a different $\mathrm{h} / \mathrm{d}$ ratio and group statistics for an organic loading rate that includes the descriptive statistics for each group. Specifically, the table includes the number of cases $(\mathrm{N})$, the mean, the standard deviation, and the estimated standard error of the mean (the standard deviation divided by $\mathrm{N}$ ). The mean performance demonstrated that a higher average performance had a significant effect on the sample rather than a lower range [10]. However, this would be a premature result and the general purpose of the t-test is to determine whether this is a real difference (statistically significant), or one that could be attributed to random chance.

\subsection{Levene's test}

Levene's test is utilized to see if $k$ samples have equal variances. Equal variances across tests are called homogeneity of variance. Some statistical tests expect that variances are equivalent across samples or tests. Levene's test can be utilized to verify that assumption; if the result is significant (the value under "Sig." is under .05 ), the two variances are significantly different. If it is not significant (Sig. is greater than .05), it means the two variances are roughly equal.

In the independent t-test output, the first two columns are named Levene's Test for Equality of Variances as one of the assumptions from the t-test is tested, i.e., the variance in the two groups are equal or homogeneous. If this assumption is violated in the data, a statistical adjustment must be performed. The F statistic in the first column and its probability in the second column (Sig., an abbreviation for significance) provides the significant value for equality of variances. If the probability of the F value (i.e., Sig.) is less than or equal to .05, then the variances in the groups being compared are different, and the condition of homogeneity of variance has not been satisfied. The results of the $\mathrm{F}$ test determine whether to 
utilize the Equal variances accepted rows or the Equal variances not accepted rows in assessing the $t$ statistic. The rules for guidance are as follows [11]:

- If the variances for the two groups are equal (i.e., Sig. > .05), at that point utilize the output in the Equal variances assumed rows.

- If the variances for the two groups are significantly different (i.e., Sig. < .05 ), at that point utilize the output in the Equal variances not assumed rows.

- Since the probability ( $\mathrm{Sig} .=.000)$ for the $\mathrm{F}$ value is less than .05 , consequently, the variances of the two groups are not equal, and thus the output in the Equal variances not assumed row ought to be utilized.

\section{SIGNIFICANCE OF BIOKINETIC PARAMETERS}

\subsection{Kinetic Coefficients with different H/D Ratios}

The Independent Samples T-Test is a parametric test used to compare the means of two independent groups, whether there is statistical evidence that the associated population means are significantly different. In this investigation, independent samples t-test was performed to determine the importance of biokinetic parameters with the difference in reactor H/D ratio and OLR. As stated in Table 1 , by default, a reactor with an $\mathrm{H} / \mathrm{D}$ ratio of more than 10 was related with a high Ks value $\mathrm{M}=1464.67(\mathrm{SD}=1478.87)$. In comparison, a reactor with an $\mathrm{H} / \mathrm{D}$ ratio less than 10 was related with a numerically smaller value of $\mathrm{Ks}$ $\mathrm{M}=252.00(\mathrm{SD}=33.94)$.

In order to test the hypothesis that reactors with different $\mathrm{H} / \mathrm{D}$ ratios are statistically different from the mean $\mathrm{Ks}$, independent samples t-tests were performed. Besides this, the study by Chan et al., [12] shows the Ks value for industrial waste is generally in the range between 850 and 5200. However, Ks values tend to vary, which is dependent on the nature of the substrate [13]. In this study, a comparison between Mean Ks shows Reactor H/D ratio $<10$ is lower than Reactor H/D ratio $>10$ because the dimension of the reactors probably has diverse microbial cultures [14]. In addition, a study by Chen et al., [15] shows a different value of Ks indicating the performance of biological treatment was lower than conventional activated sludge. The reason for this could be related to the type of wastewater and temperature used [9].

As in Table 2, the distribution of Ks is quite normal for performing a t-test, where skewness and kurtosis are lower than $|2.0|$ and kurtosis is $|9.0|$, respectively [16]. Therefore, the value of skewness shows the distribution is moderately and highly skewed when the result obtained is between 0.5 to 1 and greater than 1 , respectively. In statistics, the skewness is a measure of the asymmetry of the 
THE RELATIONSHIP BETWEEN THE BIOKINETIC PARAMETERS OF AN AEROBIC 165 GRANULAR SLUDGE SYSTEM AND THE APPLIED OPERATING CONDITIONS

probability distribution of a random variable about its mean, except if skewness is zero, the data are perfectly symmetrical [10].

Table 1. Group statistics for reactor with different $\mathrm{h} / \mathrm{d}$ ratio

\begin{tabular}{|c|l|c|c|c|c|}
\hline \multicolumn{2}{|c|}{ Reactor H/D ratio } & $\mathrm{N}$ & Mean & $\begin{array}{c}\text { Std. } \\
\text { Deviation }\end{array}$ & $\begin{array}{c}\text { Std. Error } \\
\text { Mean }\end{array}$ \\
\hline \multirow{2}{*}{$K_{s}$} & Reactor H/D ratio $>10$ & 3 & 1464.67 & 1478.865 & 853.823 \\
\cline { 2 - 6 } & Reactor H/D ratio $<10$ & 2 & 252.00 & 33.941 & 24.000 \\
\hline \multirow{2}{*}{$Y$} & Reactor H/D ratio $>10$ & 3 & 0.3500 & 0.28618 & 0.16523 \\
\cline { 2 - 6 } & Reactor H/D ratio $<10$ & 2 & 0.3000 & 0.24042 & 0.17000 \\
\hline \multirow{2}{*}{$\mu_{m}$} & Reactor H/D ratio $>10$ & 3 & 2.0900 & 3.06892 & 1.77184 \\
\cline { 2 - 6 } & Reactor H/D ratio $<10$ & 2 & 0.1350 & 0.03536 & 0.02500 \\
\hline
\end{tabular}

Table 2. Descriptive statistics associated for kinetic coefficients

\begin{tabular}{|c|c|c|c|c|c|}
\hline & & $K_{s}$ & $Y$ & $K$ & $\mu_{m}$ \\
\hline \multirow{2}{*}{$\mathrm{N}$} & Valid & 5 & 5 & 5 & 5 \\
\hline & Missing & 0 & 0 & 0 & 0 \\
\hline \multicolumn{2}{|c|}{ Mean } & 979.60 & 0.3300 & 6.3620 & 1.3080 \\
\hline \multicolumn{2}{|c|}{ Variance } & 1534977.300 & 0.056 & 141.288 & 5.856 \\
\hline \multicolumn{2}{|c|}{ Skewness } & 1.954 & 0.981 & 2.198 & 2.219 \\
\hline \multicolumn{2}{|c|}{$\begin{array}{l}\text { Std. Error of } \\
\text { Skewness }\end{array}$} & 0.913 & 0.913 & 0.913 & 0.913 \\
\hline \multicolumn{2}{|c|}{ Kurtosis } & 3.811 & -0.891 & 4.855 & 4.935 \\
\hline \multicolumn{2}{|c|}{$\begin{array}{l}\text { Std. Error of } \\
\text { Kurtosis }\end{array}$} & 2.000 & 2.000 & 2.000 & 2.000 \\
\hline
\end{tabular}

Furthermore, the assumption of homogeneity of variance was tested and satisfied through Levene's test as stated in Table 3, which is $F(3)=6.430, p=0.085$. The independent samples t-test was related to statistically insignificant effects, $\mathrm{t}(3)=$ $1.100, \mathrm{p}=0.352$. Therefore, it can be concluded that there is no statistically significant difference between the reactor $\mathrm{H} / \mathrm{D}$ ratio and the $K_{s}$ value. The contrasts between reactor $\mathrm{H} / \mathrm{D}$ ratio means might be because of external factors such as OLR range and operating conditions applied and may not be due to reactor $\mathrm{H} / \mathrm{D}$ ratio control [15].

Independent samples t-test was additionally performed to test the reactor with a different $\mathrm{H} / \mathrm{D}$ ratio of 10 related with statistically significantly different Mean $Y$ and $\mu_{m}$. Results from Table 3 demonstrated that both $Y$ and $\mu_{m}$ were related with no statistically significant effect, $\mathrm{t}(3)=0.202, \mathrm{p}=0.853$ and $\mathrm{t}(3)=0.855, \mathrm{p}=0.456$, respectively. Accordingly, this exhibited that the development and performance of aerobic granules in the reactor with an H/D ratio lower than 10 are equal to the higher. This would be a good indicator for the practical application of aerobic granules since the current SBR at a working plant in Malaysia generally has a 
low H/D ratio. This is in line with a study by Awang and Shaaban, [1] which stated that the aerobic granules were successfully developed in a low $\mathrm{H} / \mathrm{D}$ ratio by $0.7 \mathrm{~cm} / \mathrm{s}$ of SUAV.

In practice, a very high $\mathrm{H} / \mathrm{D}$ ratio is impractical, and it is difficult to get plug-flow without the risk of inhomogeneous accumulation of carbon in the granule bed [17]. This result was supported by Rocktäschel et al., [18] when the H/D ratio of an aerobic granular sludge (AGS) reactor was changed from low to high after 250 days, the granules became less stable due to the concentrations of effluent suspended solids changing. Therefore, further research by Henriet et al., [19] managed to operate an SBR with a low H/D ratio of 1.8 in order to obtain the success of AGS in lab-scale reactors, whereas Devlin and Oleszkiewicz, [20] inoculated with activated sludge from a full-scale biological removal. This is a very attractive solution as continuously operated AGS systems enable simpler retrofitting of existing activated sludge plants, but the challenge is to obtain stable granules in long-term operations [8]. Therefore, as a recommendation for future studies, the technology must be ready to be taken to a pilot scale in treating real wastewater and finally to full-scale implementation.

Table 3. Independent sample test with different $\mathrm{h} / \mathrm{d}$ ratio

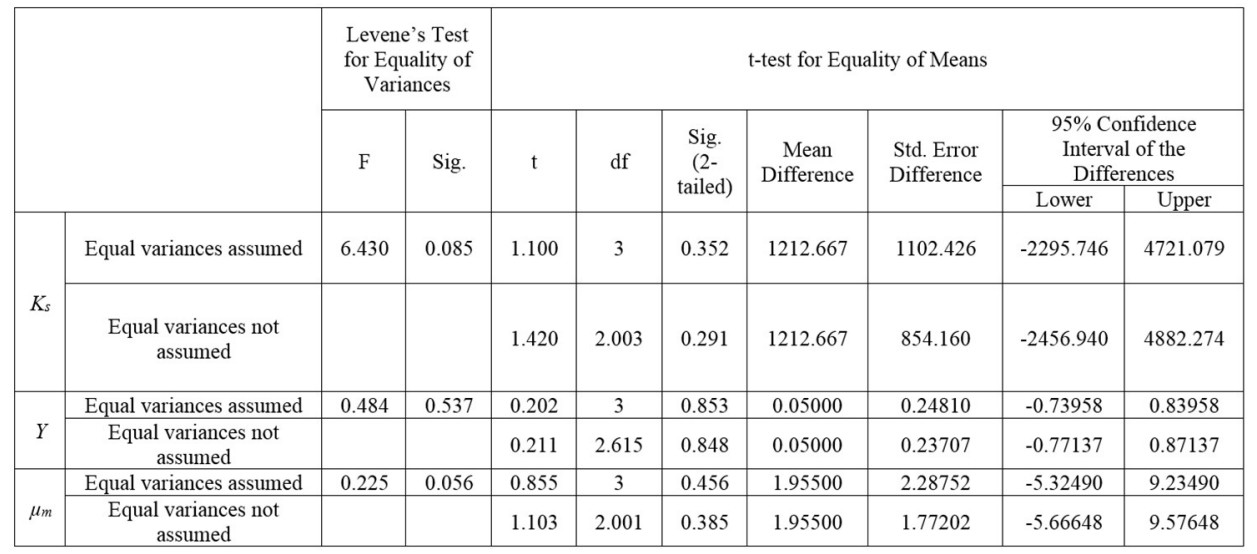

\subsection{Kinetic Coefficients with OLR}

As stated in Table 4, by default, OLR exceeding $0.5 \mathrm{~kg}$ CODs $/ \mathrm{m}^{3} \mathrm{~d}(\mathrm{~N}=2)$ was related to high $\mathrm{Y}$ value $\mathrm{M}=0.5750(\mathrm{SD}=0.14849)$. In comparison, $\mathrm{OLR}$ under 0.5 $\mathrm{kg}$ CODs $/ \mathrm{m}^{3}$ d $(\mathrm{N}=3)$ was related to a numerically smaller $\mathrm{Y}$ value, $\mathrm{M}=0.1667(\mathrm{SD}=0.03512)$. To test the hypothesis that a difference in OLR of 0.5 $\mathrm{kg}$ CODs $/ \mathrm{m}^{3} \mathrm{~d}$ was related to a statistically significantly different Mean $\mathrm{Y}$, an independent sample t-test was performed. As seen in Table 4, the Y distribution is quite normal for the purpose of performing a t-test, where the values of 
THE RELATIONSHIP BETWEEN THE BIOKINETIC PARAMETERS OF AN AEROBIC 167 GRANULAR SLUDGE SYSTEM AND THE APPLIED OPERATING CONDITIONS

skewness and kurtosis are lower than $|2.0|$ and kurtosis $|9.0|$, respectively [16]. In the study by Mardani et al., [3] the values of $\mathrm{Y}$ were increasing with the increase in MLSS concentrations. This clearly shows that the type of substrate and bacteria can have a significant effect on the determination of the biokinetic coefficients.

The values of $\mathrm{Y}$ in the contact stabilization process were decreasing with the increase in MLSS concentrations because the amount of biomass produced by the growth during the removal of the substrate in the stabilization tank decreases with increasing MLSS concentration [6]. On the other hand, increasing the MLSS concentration was also found to decrease the maximum rate of growth of the biomass and saturation constant, which could also be attributed to the same reason given before [21]. In order to determine which biokinetic parameter has the greatest influence on the effluent substrate concentration, the analysis of homogeneity of variance should be performed.

Table 4. Group statistic for organic loading rate

\begin{tabular}{|c|c|c|c|c|c|}
\hline \multicolumn{2}{|c|}{ Organic Loading Rate } & $\mathrm{N}$ & Mean & $\begin{array}{c}\text { Std. } \\
\text { Deviation }\end{array}$ & $\begin{array}{c}\text { Std. Error } \\
\text { Mean }\end{array}$ \\
\hline \multirow{2}{*}{$Y$} & Organic loading rate $>0.5$ & 2 & 0.5750 & 0.14849 & 0.10500 \\
\cline { 2 - 6 } & Organic loading rate $<0.5$ & 3 & 0.1667 & 0.03512 & 0.02028 \\
\hline \multirow{2}{*}{$\mu_{m}$} & Organic loading rate $>0.5$ & 2 & 0.1700 & 0.01414 & 0.01000 \\
\cline { 2 - 6 } & Organic loading rate $<0.5$ & 3 & 2.0667 & 3.09090 & 1.78453 \\
\hline \multirow{2}{*}{$K$} & Organic loading rate $>0.5$ & 2 & 0.3050 & 0.04950 & 0.03500 \\
\cline { 2 - 6 } & Organic loading rate $<0.5$ & 3 & 10.4000 & 14.88049 & 8.59126 \\
\hline
\end{tabular}

Furthermore, the assumption of homogeneity of variances was tested and fulfilled by Levene's test as tabulated in Table 5, $\mathrm{F}(1)=34.657$, $\mathrm{p}=0.010$. The Sig. value for $Y$ from Levene's $F$ test is significant under 0.05 , which showed that the variability in the OLR is significantly different, contributed by the changed OLR range applied during the development of aerobic granules. Whereas, the independent sample $t$-test was related to a no statistically significant effect, $t(1)=$ $3.818, \mathrm{p}=0.149$. Consequently, it can be concluded that there is no statistically significant difference between the OLR and Y values [22]. The contrasts between OLR Means might be because of external factors such as operating conditions, especially settling time applied, and may not be due to OLR control.

The settling time is considered a significant invention of AGS [8]. In the SBR system, biosolids-liquid separation takes place before the effluent is withdrawn at the end of each cycle. Other than settling time, the external factors that might affect HRT represent the retention time of the substrate at a certain period of cycle time over volume exchange ratio (VER). Furthermore, Zhou et al., [23] utilized a combinational approach, considering HRT as an evaluation index to discuss 
factors such as maximum specific removal rate $(\mathrm{K}), \mathrm{KS}, \mu \max$, and observed yield coefficient (Yobs ).

Independent samples t-test was also performed to test whether the differences in OLR were related to statistically significantly different Mean $\mu \mathrm{m}$ and K. Results from Table 5 demonstrated that both $\mu \mathrm{m}$ and $\mathrm{K}$ were associated with a not statistically significant effect, $\mathrm{t}(3)=-0.823, \mathrm{p}=0.471$ and $\mathrm{t}(3)=-0.910, \mathrm{p}=0.430$, respectively. Accordingly, this indicated the applied OLR from 0.32 to $0.63 \mathrm{~kg}$ CODs $/ \mathrm{m}^{3} \mathrm{~d}$ range are not wide, and this led to a not statistically significant effect. Thus, this indicates that biomass production depended on OLR, and this fits well with earlier assumptions of the first-order reaction characteristics of sewage. The results also revealed that for comparatively equal effluent performances, the production of biomass in an SBR with a high $\mathrm{H} / \mathrm{D}$ ratio is always greater than for a low $\mathrm{H} / \mathrm{D}$ ratio [1].

Table 5. Independent sample test for effect of OLR

\begin{tabular}{|c|c|c|c|c|c|c|c|c|c|c|}
\hline & \multicolumn{2}{|c|}{$\begin{array}{c}\text { Levene's Test for } \\
\text { Equality of } \\
\text { Variances }\end{array}$} & \multicolumn{7}{|c|}{ t-test for Equality of Means } \\
\hline & & \multirow[t]{2}{*}{$\mathrm{F}$} & \multirow[t]{2}{*}{ Sig. } & \multirow[t]{2}{*}{$\mathrm{t}$} & \multirow[t]{2}{*}{$\mathrm{df}$} & \multirow{2}{*}{$\begin{array}{l}\text { Sig. (2- } \\
\text { tailed) }\end{array}$} & \multirow{2}{*}{$\begin{array}{c}\text { Mean } \\
\text { Difference }\end{array}$} & \multirow{2}{*}{$\begin{array}{l}\text { Std. Error } \\
\text { Difference }\end{array}$} & \multicolumn{2}{|c|}{$\begin{array}{c}95 \% \text { Confidence Interval of } \\
\text { the Differences }\end{array}$} \\
\hline & & & & & & & & & Lower & Upper \\
\hline \multirow{2}{*}{ Y } & $\begin{array}{l}\text { Equal } \\
\text { variances } \\
\text { assumed }\end{array}$ & 34.657 & 0.010 & 4.948 & 3 & 0.016 & 0.40833 & 0.08252 & 0.14571 & 0.67096 \\
\hline & $\begin{array}{l}\text { Equal } \\
\text { variances not } \\
\text { assumed }\end{array}$ & & & 3.818 & 1.075 & 0.149 & 0.40833 & 0.10694 & -0.74519 & 1.56186 \\
\hline \multirow{2}{*}{$\mu_{m}$} & $\begin{array}{l}\text { Equal } \\
\text { variances } \\
\text { assumed }\end{array}$ & 9.252 & 0.056 & -0.823 & 3 & 0.471 & -1.89667 & 2.30383 & -9.22848 & 5.43515 \\
\hline & $\begin{array}{l}\text { Equal } \\
\text { variances not } \\
\text { assumed }\end{array}$ & & & -1.063 & 2.000 & 0.399 & -1.89667 & 1.78456 & -9.57453 & 5.78120 \\
\hline \multirow{2}{*}{ K } & $\begin{array}{l}\text { Equal } \\
\text { variances } \\
\text { assumed }\end{array}$ & 9.226 & 0.056 & -0.910 & 3 & 0.430 & -10.0950 & 11.0913 & -45.39245 & 25.20245 \\
\hline & $\begin{array}{l}\text { Equal } \\
\text { variances not } \\
\text { assumed }\end{array}$ & & & -1.175 & 2.000 & 0.361 & -10.0950 & 8.59133 & -47.05933 & 26.86933 \\
\hline
\end{tabular}

\section{CONCLUSION}

The biokinetic parameters evaluated from this study can be useful in operating the AGS by using an SBR system efficiently. The values obtained were used to design a new prototype for AGS for treating low strength as well as high strength wastewaters. Other biokinetic parameter results can be summarized as :

- Biomass production ( $\mathrm{Y}$ and $\mu \mathrm{max}$ ) relied relatively upon an increase in OLR and reactor $\mathrm{H} / \mathrm{D}$ ratio. 
- Aerobic granules developed in reactors with a high H/D ratio have a shorter setup time and are more active in contrast with low H/D ratio reactors.

\section{ACKNOWLEDGEMENTS}

This study was sponsored by Research University Individual Grant (1001/PAWAM/8014038) and Short-Term Grant (304/PAWAM/6315151) provided by Universiti Sains Malaysia. Hamiruddin, NA acknowledges the Universiti Sains Malaysia for their support in her USM fellowship 2/2019.

\section{REFERENCES}

1. Awang, NA and Shaaban, MD 2016. Effect of Variable and Low Organic Loading Rate on Formation Aerobic Granular Sludge in Sewage Treatment. Journal of Advanced Research in Materials Science 112, 1-10.

2. Mizzouri, NS and Shaaban, G 2013. Kinetic and hydrodynamic assessment of an aerobic purification system for petroleum refinery wastewater treatment in a continuous regime. International Biodeterioration. \& Biodegradable 83, 19.

3. Mardani, Sh, Mirbagheri, M, Amin, M and Ghasemian M 2011. Determination of biokinetic coefficients for activated sludge processes on municipal wastewater. Journal of Environmental Health Science \& Engineering 8, 25-34.

4. Okpokwasili, GC and Nweke, CO 2005. Microbial growth and substrate utilization kinetics. Journal Biotechnology 5, 305-317.

5. Winkler, MKH, Meunier, C, Henriet, O, Mahillon, J, Suárez-Ojeda, ME, DelMoro, G, DeSanctis, M, Dilaconi, C and Weissbrodt, DG 2018. An integrative review of granular sludge for the biological removal of nutrients and recalcitrant organic matter from wastewater. Journal Chemical Engineering 336, 489-502.

6. Amaldos, M, Amerlinck, Y, Rehman, U, Rehman, TC, Van Hoey, W and Naessens, S 2015. Understanding conventional modeling concepts in novel wastewater treatment processes. Water Research 70, 458-470.

7. Zhang, Q, Hu, J and Lee, DJ 2016. Aerobic granular processes: current research trends. Bioresource Technology 210, 74-80.

8. Nancharaiah, YV and Kiran, KRRG 2018. Aerobic granular sludge technology: mechanisms of granulation and biotechnological applications. Bioresource Technology 247, 1128-1143. 
9. Gupta, VK, Ali, I, Saleh, TA, Nayak, A and Agarwal, S 2012. Chemical treatment technologies for waste-water recycling-an overview. RSC Advances 2, 6380-6388.

10. Cohen, J, West, SG and Aiken, LS 2007. Applied multiple regression/correlation analysis for the behavioural sciences. Routledge.

11. Levene, H, West, SG and Aiken, LS 1960. Robust tests for equality of variances". In: Olkin,I.(Ed.). Contributions to Probability and Statistics. Stanford University Press, Palo Alto, California, 278-292.

12. Chen, Y, Jiang, W, Liang, DT and Tay, JH 2008. Biodegradation and kinetics of aerobic granules under high organic loading rates in sequencing batch reactor. Applied Microbiology and Biotechnology 79, 301-308.

13. Asadi, A, Zinatizadeh, AA and Sumathi, S 2014. Industrial estate wastewater treatment using single up-flow aerobic/anoxic sludge bed (UAASB) Bioreactor: a kinetic evaluation study. Environment. Program Sustain. Energy 33, 1-9.

14. Lateef, A, Chaudhry, MN and Ilyas, S 2013. Biological treatment of dairy wastewater using activated sludge. Science Asia 39, 179-185.

15. Chen, HY, Hong, PK, Yang, PY, Yang, KKNgSF and Lee, CH 2015. A pilot study on suspended activated sludge process augmented with immobilized biomass for simultaneous nitrification and denitrification. Journal of Water Reuse and Desalination 5, 157-165.

16. Schmider, E, Ziegler, M, Danay, E and Buehner, M 2010. Is it really Robust. Methodology European Journal of Research Methods for the Behavioral and Social Sciences, 147-151.

17. Winkler, MKH, Kleerebezem, R, Strous, M, Chandran, $\mathrm{K}$ and Van Loosdrecht, MCM 2013. Factors influencing the density of aerobic granular sludge. Applied Microbiology Biotechnology 97, 7459-7468.

18. Rocktäschel, T, Klarmann, C, Helmreich, B, Ochoa, J, Boisson, P, Sørensen, $\mathrm{KH}$ and Horn, H 2013. Comparison of two different anaerobic feeding strategies to establish a stable aerobic granulated sludge bed. Water Resource 47, 6423-6431.

19. Henriet, O, Henriet, CCP and Mahillon, J 2016. Improving phosphorus removal in aerobic granular sludge processes through selective microbial management. Bioresource Technology 211, 298-306.

20. Devlin, TR and Oleszkiewicz, JA 2018. Cultivation of aerobic granular sludge in continuous flow under various selective pressure. Bioresource Technology 253, 281-287.

21. Mehrabadi, ZS and Zinatizadeh, A 2014. Performance of a compartmentalized activated sludge (CAS) system treating a synthetic antibiotics industrial wastewater (SAW). Journal of Water Process Engineering 3, 26-33. 
THE RELATIONSHIP BETWEEN THE BIOKINETIC PARAMETERS OF AN AEROBIC 171 GRANULAR SLUDGE SYSTEM AND THE APPLIED OPERATING CONDITIONS

22. Kaewsuk, J, Thorasampan, W, Thanuttamavong, M and Tae, G 2010. Kinetic development and evaluation of membrane sequencing batch reactor ( MSBR) with mixed cultures photosynthetic bacteria for dairy wastewater treatment. Journal Environment Management 91, 1161-1168.

23. Zhou, D, Niu, S, Xiong, Y, Yang, Y and Dong, S 2014. Microbial selection pressure is not a prerequisite for granulation: dynamic granulation microbial com- munity study in a complete mixing bioreactor. Bioresource Technology 161, 102-108.

Editor received the manuscript: 18.10 .2020 